\title{
Pendampingan dan Analisis Kelayakan Usaha Kerupuk Ikan “Abizar" di Desa Pangkahkulon
}

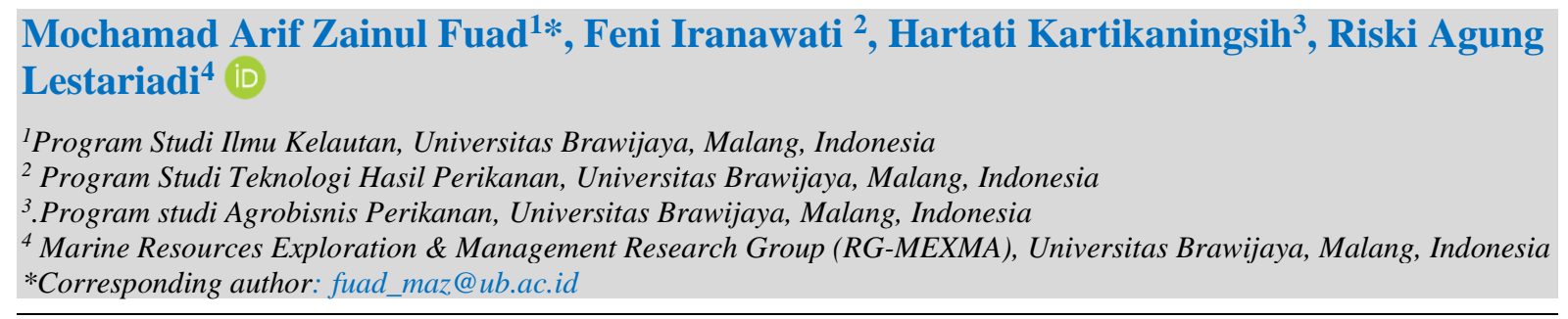

\begin{abstract}
Abstrak
Kegiatan pengabdian kepada masyarakat ini bertujuan untuk memberikan pendampingan dalam pengembangan dan analisis kelayakan usaha kerupuk ikan pada home industry Abizar di Desa Pangkahkulon Ujung PangkahGresik dari berbagai aspek. Pendampingan dilakukan dengan beberapa kegiatan antara lain pengenalan dan pemberian bantuan alat produksi, pelatihan pemasaran, dan pelatihan pengelolaan keuangan. Sedangkan analisis kelayakan usaha ditinjau dari beberapa aspek yaitu aspek teknis produksi, manajemen, pemasaran, legalitas dan aspek keuangan. Hasil analisis menunjukkan bahwa UKM secara umum layak dijalankan dari berbagai aspek di atas. Dari aspek finansial yang menjadi indikator utama kelayakan usaha, terdapat profit ratio yang sangat besar, Net B/C ratio yang mencapai 5,05, Profitabilitas 40\%, dan $\mathrm{R} / \mathrm{C}$ Ratio 1,5 serta payback period kurang dari setengah. setahun, maka usaha ini layak untuk diusahakan dan dapat dilanjutkan. Berdasarkan studi kelayakan usaha juga dapat disimpulkan bahwa pendampingan usaha dengan memberikan bantuan alat produksi tidak memberikan beban keuangan baru bagi pengusaha tetapi justru meningkatkan efisiensi dan keuntungan usaha. Namun masih perlu pembenahan terutama dari aspek legalitas usaha karena UKM mitra belum memiliki legalitas sama sekali.
\end{abstract}

Kata Kunci: UKM Kerupuk Ikan, Pangkahkulon, Pendampingan produksi

\section{Abstract}

This community service activity aims to provide assistance in the development and analysis of the feasibility of the fish cracker business at the Abizar home industry in Pangkahkulon Village, Ujung Pangkah-Gresik from various aspects. Assistance is carried out through several activities, including the introduction and provision of production equipment assistance, marketing, and financial management training. While the business analysis is reviewed from several technical, management, marketing, legal and financial aspects. The results of the analysis show that SMEs are generally feasible to run from the various aspects above. From the financial aspect which is the main indicator of the business, there is a very large profit ratio, the Net B/C ratio reaches 5.05, Profitability is $40 \%$, and the R/C Ratio is 1.5 and the payback period is less than half. a year, then this effort is feasible and can be continued. Based on research, profits can also be obtained from business support by providing tools, but it does not increase efficiency and effort. However, it still needs improvement, especially from the aspect of business legality because partner SMEs do not have legality at all.

Keywords: Fish Cracker SMEs, Pangkahkulon, Production Assistance

\section{INTRODUCTION}

Kerupuk ikan merupakan salah satu makanan ringan tradisional yang sangat populer dan banyak disukai masyarakat Indonesia (Agustina \& Saputro, 2018; Erlina et al., 2016) dengan potensi pasar yang luas baik dari kalangan bawah sampai kalangan atas (Sukrie \& Nadia, 2010; Wahyuni et al., 2017). Potensi pasar yang besar ini menarik minat masyarakat untuk menjadi pengusaha kerupuk ikan. Salah satu wilayah yang menjadi sentra kerupuk ikan adalah Desa Pangkahkulon Kecamatan Ujung Pangkah, Kabupaten Gresik. Desa ini sebagian besar wilayahnya merupakan daerah pertambakan yang menjadi sumber penghasilan

$\begin{array}{ll}\text { History: } & \\ \text { Received } & \text { : June 26, } 2021 \\ \text { Revised } & \text { : July 28, 2021 } \\ \text { Accepted } & \text { : August 03, 2021 } \\ \text { Published } & \text { : August 25, 2021 }\end{array}$


penduduknya. Tambak di Desa Pangkahkulon umumnya merupakan tambak tradisional dengan produk utamanya Ikan bandeng dan Udang dengan produk sampingan jenis ikan lainnya seperti ikan payus, ikan laosan dan masih banyak lagi lainnya (Iranawati et al., 2017). Sehingga tidak heran jika Desa ini terkenal dengan produk perikanan dan turunanannya termasuk kerupuk ikan. Usaha yang perupuk ikan tersebut ada yang menjadi sumber pendapatan utama maupun sampingan bagi penduduk desa. Hal ini karena proses pembuatan kerupuk ikan dapat dilakukan dengan peralatan sederhana maupun moderen, sehingga banyak rumah tangga yang melakukannya dalam skala mikro (Kusumaningrum \& Asikin, 2016). Industri kerupuk ikan di Desa Pangkahkulon tahun 2020 berjumlah 68 unit yang umumnya masih berskala mikro atau lebih ke arah Industri Rumah Tangga (IRT) dengan pekerja 2-5 orang. Pengusaha kerupuk ikan tersebar dalam 4 Dusun yaitu Dusun Krajan 1, Krajan 2, Druju dan Kalingapuri dengan jumlah industri terbanyak berada di Dusun Krajan 2 sekitar 20 UMKM.

Salah satu pengusaha kerupuk ikan di Dusun Krajan 2 Desa Pangkahkulon adalah Bapak Dzalil dengan nama usaha dagang "ABIZAR" yang sudah kurang lebih sudah berlangsung 9 tahun. Pada awal mulanya proses pembuatan kerupuk dilakukan secara manual hanya dengan tenaga tangan baik dalam proses pencampuran adonan sampai dengan pemotongan kerupuk. Sehingga kapasitas produksi hanya berkisar $5 \mathrm{~kg}$ perhari. Namun saat ini proses pembuatan kerupuk ikan pada UKM ini sudah semi moderen dengan digunakannya beberapa peralatan pendukung proses produksi antara lain yaitu Mixer adonan kerupuk, lemari pendinginan, dan mesin pemotong kerupuk otomatis. Penggunaan peralatan semi moderen ini mampu meningkatkan kuantitas dan kualitas kerupuk yang dihasilkan (Firdaus \& Intyas, 2020; M. A. Z. Fuad et al., 2020; Kurniasih et al., 2019; Sriningsih et al., 2017; Wahdah et al., 2016). Sebagian besar peralatan utama dan penunjang produksi tersebut merupakan hibah/bantuan dari Program Pengembangan Desa Mitra tahun 2019 dan 2020 dari Direktorat Riset dan Pengabdian Masyarakat (DRPM) Kemenristekdikti melalui Universitas Brawijaya, Malang. Penggunaan peralatan moderen dalam pembuatan kerupuk selain meningkatkan kuantitas dan kualitas produk juga berpengaruh terhadap biaya produksi, yaitu penambahan kebutuhan listrik untuk mesin produksi. Mesin produksi dengan daya listrik relatif besar yang berkisar antara 500-750 watt dapat meningkatkan biaya produksi sedangkan di lain pihak pengusaha kerupuk tidak serta merta dapat meningkatkan harga jual produknya. Kegiatan yang dilakukan untuk meningkatkan usaha UKM adalah dengan pendampingan.

Pendampingan bagi mitra pengabdian dilakukan dengan metode Participatory Rural Apprasial (PRA). Metode PRA merupakan metode yang terdiri dari pendekatan tertentu yang mendorong mitra untuk turut serta secara langsung dan berperan aktif dalam mencari solusi atas permasalahan yang ada. Dengan metode ini diharapkan mitra dapat lebih banyak terlibat langsung dalam pelaksanaan kegiatan dan memiliki rasa tanggung jawab yang tinggi pada pelaksaan kegiatan. Metode PRA sangat sesuai di terapkan pada kegiatan pengabdian yang melibatkan mitra secara aktif agar dapat berjalan dengan baik sesuai dengan tujuan. Beberapa kegiatan pengabdian masyarakat telah sukses dilakukan dengan pendekatan ini antara lain yaitu kegiatan pengembangan Desa Wisata (Hudayana et al., 2019), industri kerupuk singkong (Mokhtar, 2019), agribisnis ikan tawar (Margowati et al., 2018) dan pengolahan hasil perikanan (Setyaningrum \& Hartanto, 2020). Pendampingan proses produksi yang dilakukan meliputi tata-cara penggunaan dan perawatan mesin pengaduk adonan (Mixer), Rak pendingin, mesin pemotong kerupuk, dan mesin pengemas (hand sealer). Pendampingan usaha yang dilakukan kepada mitra meliputi pendampingan proses produksi, pendampingan manajemen keuangan, dan pendampingan pemasaran. Untuk itu kegiatan pengabdian masyarakat ini bertujuan untuk memberi pendampingan terhadap UKM kerupuk ikan dan membantu analisis kelayakan usaha dari aspek ekonomi. Harapannya dengan penggunaan alat moderen tidak menjadi beban 
keuangan baru bagi UKM namun dapat meningkatkan efisiensi usaha sehingga menambah keuntungan usaha. Selain itu hasil kajian ini diharapkan juga dapat dijadikan rujukan bagi masyarakat yang ingin menjadi pengusaha kerupuk ikan.

\section{MATERIALS AND METHODS}

Mitra kegiatan pengabdian ini adalah UKM kerupuk ikan "ABIZAR” yang berada di Desa Pangkahkulon, Kecamatan Ujungpangkah Kabupaten Gresik-Jawa Timur. Kegiatan ini dilakukan dengan beberapa tahapan waktu yaitu introduksi Teknologi Tepat Guna (TTG) dan pendampingan usaha yang dilakukan sejak bulan April 2019 dan analisis kelayakan usaha yang dilakukan pada bulan April sampai dengan Mei 2021. Pendampingan bagi mitra pengabdian dilakukan dengan metode Participatory Rural Apprasial (PRA). Metode PRA merupakan metode yang terdiri dari pendekatan tertentu yang mendorong mitra untuk turut serta secara langsung dan berperan aktif dalam mencari solusi atas permasalahan yang ada. Dengan metode ini diharapkan mitra dapat lebih banyak terlibat langsung dalam pelaksanaan kegiatan dan memiliki rasa tanggung jawab yang tinggi pada pelaksaan kegiatan. Metode PRA sangat sesuai di terapkan pada kegiatan pengabdian yang melibatkan mitra secara aktif agar dapat berjalan dengan baik sesuai dengan tujuan. Beberapa kegiatan pengabdian masyarakat telah sukses dilakukan dengan pendekatan ini antara lain yaitu kegiatan pengembangan Desa Wisata (Hudayana et al., 2019), industri kerupuk singkong (Mokhtar, 2019), agribisnis ikan tawar (Margowati et al., 2018) dan pengolahan hasil perikanan (Setyaningrum \& Hartanto, 2020). Pendampingan proses produksi yang dilakukan meliputi tata-cara penggunaan dan perawatan mesin pengaduk adonan (Mixer), Rak pendingin, mesin pemotong kerupuk, dan mesin pengemas (hand sealer). Pendampingan usaha yang dilakukan kepada mitra meliputi pendampingan proses produksi, pendampingan manajemen keuangan, dan pendampingan pemasaran.

Pengumpulan data dilakukan dengan beberapa metode antara lain yaitu (1) Observasi, dengan cara mengamati secara langsung proses produksi dan kondisi UKM; (2) Wawancara dengan pelaku usaha, dalam hal ini wawancara dilakukan dengan responden sebanyak 3 orang yaitu pemilik dan pekerja pada UKM ABIZAR. Sedangkan metode yang ke tiga (3) yaitu dengan dokumentasi, yaitu dengan cara mendokumetasikan kondisi UKM dan proses produksi kerupuk ikan. Selain tiga metode diatas, juga dilakukan pencarian pustaka yang berkaitan tentang usaha kerupuk di Desa Pangkahkulon. Data yang diperoleh melalui beberapa metode tersebut diatas selanjutnya dianalisis baik secara deskriptif kualitatif maupun kuantitatif. Penelitian deskriptif umumnya ditujukan untuk menggambarkan kondisi secara detail suatu kejadian atau keadaan (M A Z Fuad, Sartimbul, et al., 2019). Pada kasus ini analisis deskriptif akan membahas tentang kondisi mitra dan proses pembuatan kerupuk ikan. Sedangkan analisis kuantitatif dilakukan untuk menghitung kelayakan usaha yang dilakukan oleh mitra terutama berdasarkan aspek keuangan.

\section{RESULTS AND DISCUSSION}

\section{Hasil}

\section{Pendampingan Usaha}

\section{Introduksi TTG dan Pendampingan Proses Produksi}

Proses pembuatan kerupuk yang dilakukan mitra sebelumnya masih secara tradisional dengan alat sederhana dan manual. Melalui Program pengembangan Desa Mitra (PPDM) mitra diberikan hibah peralatan produksi secara bertahap antara lain yaitu Mesin pengaduk adonan (Mixer), Mesin pemotong kerupuk otomatis, Chest Freezer dan Rak pendingin adonan, serta alat pengemas /sealer (Gambar 1). Pemberian bantuan alat juga dibarengi dengan pelatihan 
penggunaan dan perawatan alat. Pendampingan dan pelatihan dalam penggunaan alat sangat diperlukan karena alih teknologi dari manual ke alat yang semi moderen tidak dapat langsung dilakukan oleh pengusaha kecil. Hal ini karena ada kepercayaan yang berkembang di sebagian masyarakat dan pengusaha kecil jika pembuatan kerupuk dengan mesin memiliki rasa kerupuk yang berbeda dengan jika dibuat secara manual. Dalam hal ini rasa kerupuk yang dibuat secara manual dianggap oleh lebih enak daripada dibuat dengan mesin meskipun pada kenyataannya tidak demikian. Kualitas kerupuk dengan mesin jelas lebih baik daripada jika dibuat secara manual dengan tangan (Firdaus \& Intyas, 2020; M. A. Z. Fuad et al., 2020).

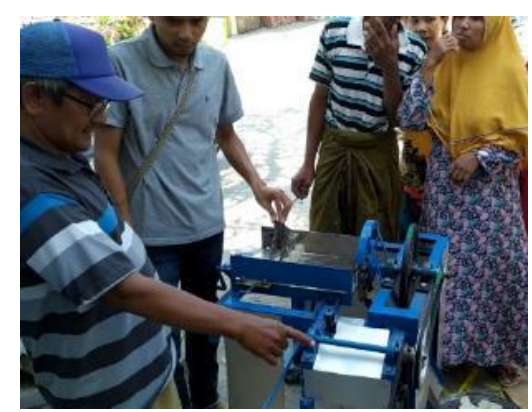

Mesin Pemotong Kerupuk

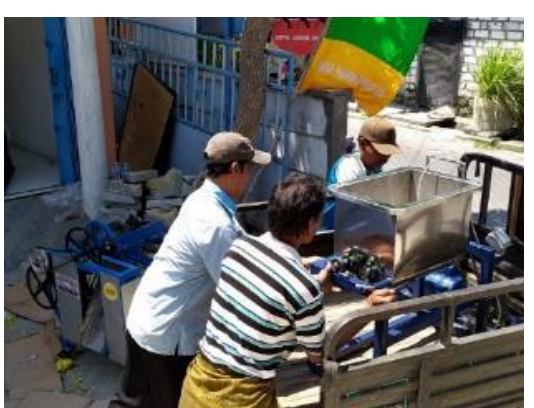

Mixer Adonan

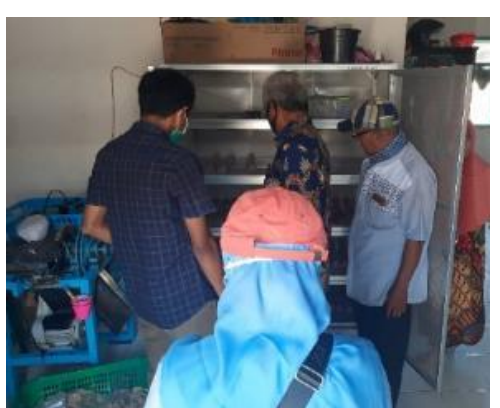

Rak pendingin adonan

Gambar 1. Hibah Alat Produksi

\section{Pendampingan Manajemen Keuangan}

Manajemen keuangan merupakan faktor yang sangat penting bagi UKM untuk dapat berkembang. Kemampuan pelaku UKM dalam membuat laporan keuangan berpengaruh positif dalam peningkatan kinerja dan pendapatan UKM (Harahap, 2014; Rahmayuni, 2017). Sehingga semakin baik manajemen keungan maka kinerja UKM akan semakin meningkat. Pendampingan manajemen keuangan di lakukan dengan cara memberikan pelatihan tata-cara pembuatan laporan keuangan sederhana bagi mitra. Pelatihan pembuatan laporan keuangan sederhana dilakukan pada bulan Agustus 2020. Laporan keuangan sederhana ini berisi arus kas yang terdiri dari perhitungan biaya total produksi, termasuk menghitung upah pekerja dimana pemilik yang sekaligus juga sebagai bagian dari tenaga kerja, dan total pendapatan. Pemahaman dan ketrampilan pembuatan laporan keuangan sangat tergantung dari tingkat pendidikan dan lama usaha yang telah dijalankan (Latifiana, 2017). Dengan laporan yang sederhana yang disesuaikan dengan tingkat pendidikan mitra, diharapkan mitra dapat dengan mudah memahami dan mempraktekkan pengetahuan yang di dapatkan.

\section{Pendampingan Pemasaran}

Kapasitas produksi kerupuk yang meningkat harus diikuti dengan pemasaran yang baik untuk menghindari kelebihan stok. Saat awal terjadi Pandemi Covid 19 antara bulan AprilOktober 2020 penjualan menurun drastis. UKM hanya mengandalkan pembelian secara perseorangan dari wiliyah sekitar Desa Pangkahkulon saja. Pembeli besar dari luar wilayah mengalami kendala dalam distrubusi dan permintaan kerupuk yang menurun sehingga omset turun sampai hanya 50-60\%. Untuk membantu mengatasi masalah ini maka dilakukan penyuluhan dan pelatihan pemasaran secara online dengan tujuan memperluas pangsa pasar. Penjualan secara online dipercaya akan membawa dampak positif bagi UKM yaitu meningkatnya penetrasi dan jangkauan pasar (Aliviyanti et al., 2021; Mochamad Arif Zainul Fuad et al., 2020; Purnengsih et al., 2021; Riyadi \& Mujanah, 2021; Suwarni et al., 2020). Pelatihan ini dilakukan pada tanggal 27 oktober 2020 dengan mengundang narasumber dari perwakilan marketplace online (shopee Indonesia), Dinas Perikanan, dan pelaksana kegiatan pengabdian (Gambar 2). Namun demikian pelatihan ini kurang membawa dampak bagi 
pemasaran karena pelaku UKM merasa mengalami kesulitan dalam manajemen penjualan secara online.
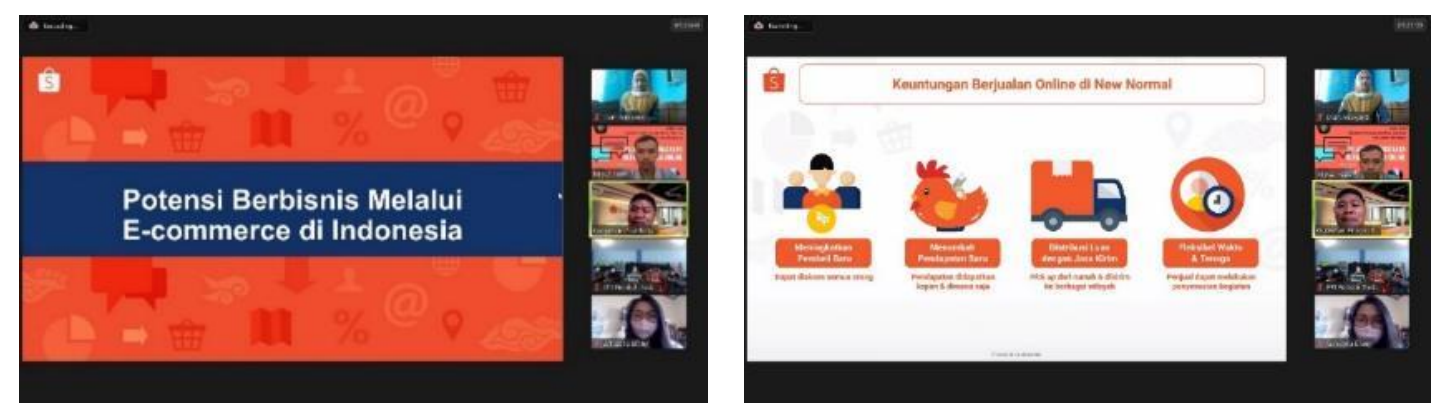

Gambar 2. Sosialisasi dan Pelatihan Penjualan Online

\section{Analisis Kelayakan Usaha \\ Aspek Teknis Produksi}

UKM Kerupuk ikan “ABIZAR” menempati bangunan dengan luas sekitar $90 \mathrm{~m}^{2}$ yang berdiri diatas tanah dengan luas mencapai $150 \mathrm{~m}^{2}$. Bangunan ini sekaligus menjadi rumah tinggal bagi pemilih usaha. Kondisi seperti ini sangat umum terjadi di usaha skala mikro dan kecil seperti usaha olahan ikan (Latif et al., 2017; Putri et al., 2015), kerupuk ikan (Herlambang et al., 2018), Proses produksi dilakukan dari dapur sampai dengan ruang utama rumah. Meskipun demikian, terdapat pemisahan tempat antara bahan baku dan produk yang dihasilkan sehingga sudah sesuai dengan pedoman Cara Produksi Pangan yang Baik bagi Indutri Rumah Tangga (CPPB-IRT) yang dikeluarkan oleh BPOM melalui PerkaBPOM RI Nomor HH.03.1.23.04.12.2206 Tahun 2012 Tentang Cara Produksi Pangan Yang Baik Untuk Industri Rumah Tangga. Bahan baku di tempatkan di bagian depan rumah, sedangkan proses pembuatan kerupuk dari mulai pencampuran adonan, pembuatan bentuk adonan lontongan sampai dengan perebusan berada pada dapur. Sedangkan hasil produk jadi ditempatkan di ruang tamu atau ruang utama rumah. Peralatan yang digunakan dalam proses produksi sudah didominasi oleh mesin yang berbahan dasar besi tahan karat (stainless steel) dan aluminium. Pemotongan dan pengepakan kerupuk dilakukan dengan alat yang sudah semi moderen yang dilakukan di ruang utama rumah. Tempat dan alat produksi terlihat sangat bersih dan terawat (Gambar 3).

Proses pembuatan kerupuk dapat divisualisasikan seperti pada gambar 3.dimulai dari pemilihan bahan baku yaitu Ikan,Tepung Kanji tapioka, dan bumbu serta penyedap rasa. Ikan segar diperoleh dari Tempat pelelangan Ikan (TPI) milik Desa Pangkahkulon yang berjarak kurang lebih $3 \mathrm{~km}$ dari rumah mitra. Namun demikian jika stok ikan tidak ada atau tidak sesuai yang diharapkan, maka mitra akan membeli ikan di TPI ddi esa sekitarnya. Ikan yang didapat kemudian dibersihkan dan dipisahkan antara daging dan durinya dengan alat Fish meat-Bone Separator milik BUMDES Desa Pangkahkulon yang merupakan bantuan dari PPDM dari Universitas Brawijaya tahun 2019. Alat ini mampu memisahkan daging-duri ikan dengan baik dengan kapasitas kurang lebih mampu memisahkan daging-duri ikan sebanyak 200-250 kg perjam. Sebelum ada alat ini, mitra dan produsen kerupuk ikan lainnya memisahkan daging ikan dari durinya secara manual atau pergi ke kecamatan sebelah yaitu Kecamatan Sidayu dengan jarak tempuh kurang lebih $10 \mathrm{Km}$. Dengan adanya alat ini saat ini UKM kerupuk ikan tidak perlu jauh untuk memisahkan daging-duri ikan. 


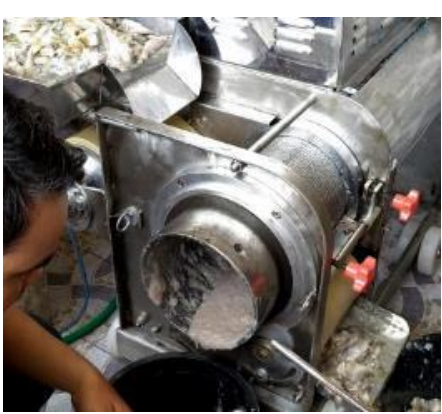

Pemisahan daging-duri ikan

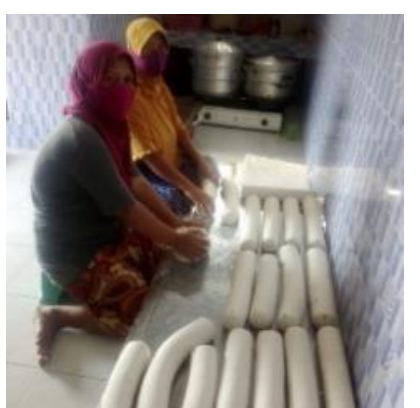

Pembuatan Bentuk

Lontongan

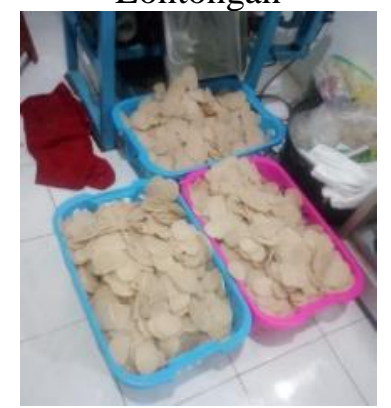

Pemotongan

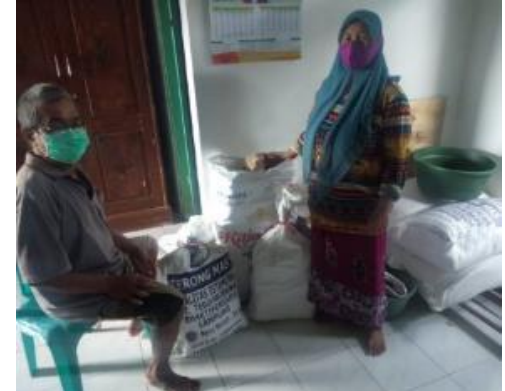

Persiapan dan penimbangan bahan

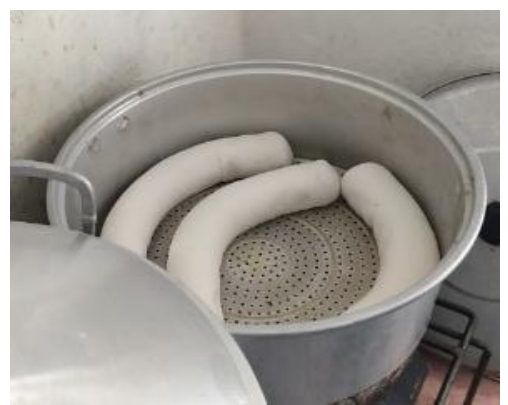

Pengukusan

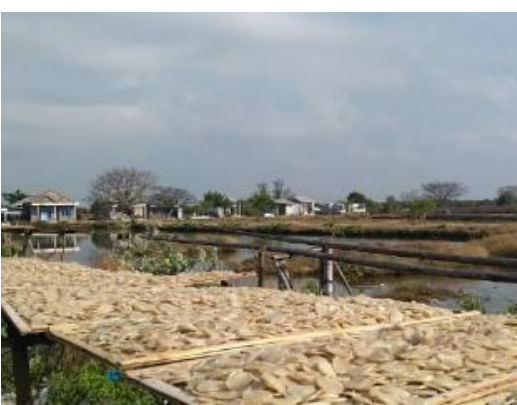

Penjemuran

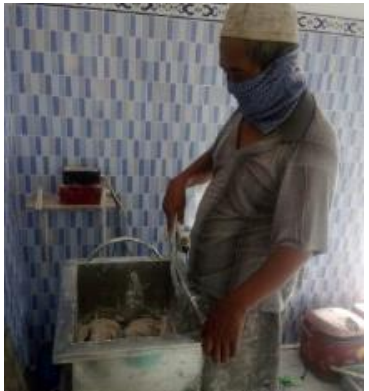

Pencampuran adonan

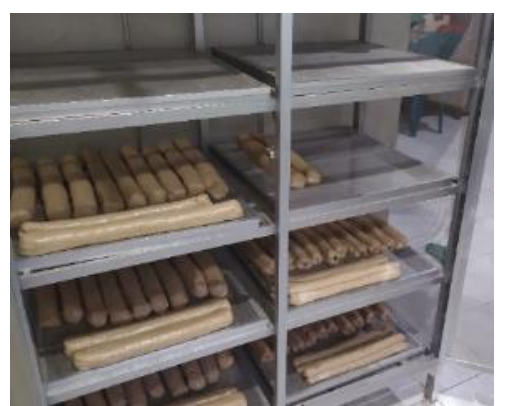

Pendinginan dalam Rak

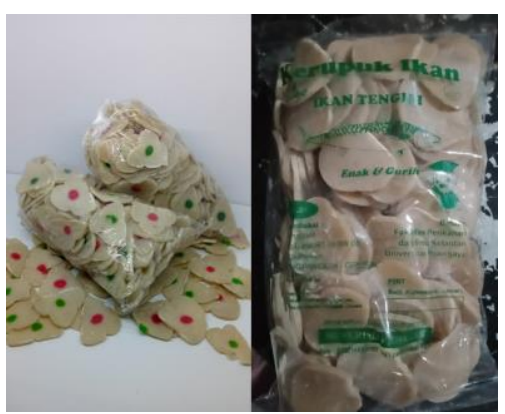

Pengepakan

Gambar 3. Proses Pembuatan Kerupuk Ikan

\section{Pemasaran}

Selama ini mitra menjual produknya dalam 2 model pembeli yaitu dijual kepada perseorangan untuk konsumsi pribadi dan dijual kepada pedagang besar. Pedagang besar yang membeli kerupuk produksi UKM ABIZAR umumnya dari wilayah Kabupaten Gresik dan sekitarnya yaitu Babat, Lamongan, Sidoarjo, Manyar, Sidayu,Bungah-Gresik dan dari Malang. Untuk perseorangan, produk diberi label dan informasi lainnya tentang produk. Penjualan tanpa label ini juga banyak ditemui di UKM produk hasil perikanan lainnya yang dijual kepada pengepul, hal ini karena pengepul akan memberi label sendiri untuk dijual kembali dengan label tersendiri (Asyari, 2016; Hidayati, 2016). Namun untuk pedagang besar kerupuk dibungkus dalam plastik dan dimasukkan dalam karung tanpa ada label atau biasa disebut jual polosan. Berdasarkan wawancara dengan pemilik usaha, proporsi penjualan antara pembeli perseorangan dengan pembeli besar adalah 40:60. Produk kerupuk ikan yang dijual memiliki beberapa variasi ukuran yaitu $500 \mathrm{gr}, 5 \mathrm{Kg}$ dan $30 \mathrm{~kg}$. untuk pembeli yang akan digunakan untuk konsumsi pribadi umumnya membeli dalam satuan 500 gr. Sedangkan untuk pembeli partai besar untuk dijual lagi umumnya dalam satuan $5 \mathrm{~kg}$ dan $30 \mathrm{~kg}$. Pemasaran produk saat ini belum mengalami kendala yang berarti bahkan cenderung terus naik sehingga mitra kewalahan dalam memenuhi permintaan pasar. 


\section{Legalitas/Hukum}

Saat ini UKM ABIZAR belum memiliki surat ijin atau sertifikat minimal yang umumnya dimiliki oleh UKM yaitu Nomor induk berusaha (NIB), ijin edar (Pangan Industri Rumah Tangga :PIRT) dari pihak yang berwenang. Belum ada perizinan minimal dalam usaha ini dikarenakan tidak adanya pengaruh dan konsekuensi peraturan hukum pemerintah terhadap produk yang belum memiliki ijin edar. Rendahnya kesadaran pemilik usaha akan pentingnya perizinan hukum usaha merupakan persoalan klasik dan ditemukan di UKM produk perikanan seperti kerupuk (Herlambang et al., 2018; Hidayati, 2016; Ihwah \& Setiyawan, 2018; Prasetyowati et al., 2019), terasi udang (Hidayati, 2016; Musthofa \& Ainiyah, 2018) ikan asin (Sarwono et al., 2018), olahan ikan bandeng (Prahutama, 2019) dan petis (Hidayati, 2016) serta ikan asap (M A Z Fuad, Iranawati, et al., 2019). Berdasarkan wawancara dengan pelaku usaha, rendahnya kesadaran untuk mengurus legalitas UKM disebabkan karena tidak adanya waktu untuk mengurus dan kurangnya pendampingan dari instansi terkait. Selain itu penjualan produk yang tidak berlabel dan ke konsumen individu secara langsung menurut mereka tidak memerlukan ijin edar karena pembeli tidak menanyakan hal tersebut. Rendahnya kesadaran tersebut menjadi tantangan bagi pelaksana kegiatan pengabdian untuk memberikan bantuan dan pendampingan dalam mengurus legalitas usaha dari mitra.

\section{Aspek Finansial}

Analisis kelayakan usaha dari aspek finansial menggunakan asumsi-asumsi produksi secara umum (Tabel 1) berdasarkan informasi dari wawancara dengan mitra. Arus pengeluaran (outflow) pada produksi kerupuk UKM ABIZAR terdiri dari biaya investasi dan biaya operasional. Berdasarkan hasil analisis (Tabel 2), total biaya investasi yang diperlukan sebesar Rp. 53,945,000 dengan komponen terbesar berasal dari sewa bangunan, mesin pemotong kerupuk, mixer, dan rak pendingin. Biaya produksi atau operasional yang dikeluarkan UKM ABIZAR dapat dikelompokkan menjadi 2, yaitu (1) biaya tetap dan (2) biaya tidak tetap. Total biaya tetap yang dikeluarkan mencapai Rp. 4,935,000 sedangkan biaya tidak tetap sebesar Rp. 10,785,000. Pada produksi kerupuk ikan, komponen dari biaya variable yang dikeluarkan oleh UKM ABIZAR terdiri dari bahan bakau utama yaitu daging ikan dan tepung tapioka, dan bahan pelengkap yaitu bumbu dan penyedap rasa, serta bahan pengemas berupa plastik kemas berlabel. Penerimaan (inflow) yang didapatkan UKM ABIZAR dalam produksi kerupuk ikan berasal dari hasil penjualan kerupuk yang mencapai $1.015 \mathrm{~kg}$ per bulan (Tabel 3). Harga penjualan yang ditetapkan UKM ABIZAR sebesar Rp. 25.000 per kg, sehingga penerimaan yang didapatkan UKM ABIZAR diproyeksikan mencapai Rp. 24,867,500. Proyeksi rugi-laba produksi kerupuk ikan di UKM ABIZAR dilakukan dengan pengurangan komponen penerimaan dengan komponen biaya, yang terdiri dari biaya tetap dan biaya operasional. Penerimaan total yang didapatkan UKM ABIZAR dalam produksi kerupuk ikan mencapai Rp. 24,867,500 sedangkan total biaya produksi kerupuk ikan mencapai Rp. 15,720,000, sehingga dihasilkan laba kotor sebesar Rp. 8,248,417. Guna menghitung laba bersih, dilakukan pengurangan laba kotor yang dihasilkan dengan pajak penghasilan usaha sesuai dengan PP No 46 Tahun 2013, sehingga laba bersih yang diperoleh UKM ABIZAR dari produksi kerupuk ikan sebesar Rp. 7,011,154.

Beberapa indikator kelayakan investasi digunakan untuk mengukur kelayakan usaha produksi kerupuk ikan yang dilakukan UKM ABIZAR (Tabel 3). Hasil analisis menunjukkan nilai Revenue Cost Ratio (R/C Ratio) produksi kerupuk ikan UKM ABIZAR sebesar 1,5 yang berarti bahwa setiap biaya produksi yang dikeluarkan akan dapat menghasilkan penerimaan sebesar 1,5 kali lebih besar. Kriteria Rentabilitas (R) digunakan untuk mengukur kemampuan usaha dalam menghasilkan laba pada produksi kerupuk di UKM ABIZAR. Hasil analisis menunjukkan nilai rentabilitas sebesar $40 \%$. Nilai ini mengindikasikan bahwa usaha produksi kerupuk ikan di UKM ABIZAR mampu menghasilkan laba $40 \%$ dari modal yang ditanamkan. 
Selain itu, nilai Net Present Value (NPV) didapatkan sebesar Rp. 18,115,284.62 untuk jangka waktu proyek selama 5 tahun pada tingkat diskon rate $14 \%$ dan periode pengembalian modal (payback period) selama 0,47 tahun. Nilai Net B/C ratio yang mencapai 5,03 mengindikasikan usaha ini memiliki kentungan yang besar. Sebagai perbandingan, rata-rata usaha pengolahan Kerupuk ikan di Kecamatan Seruyan Hilir Kabupaten Seruyan Kalimantan Tengah menghasilkan NetB/C 2,76 dengan pengembalian modal lebih dari 3 tahun (Winarti et al., 2018), kemudian di Kota Langsa, Aceh Nilai net B/C usaha kerupuk hanya 1,15 dengan waktu pengembalian modal 4,5 tahun (Nadya \& Yusnawati, 2018). Namun angka rasio tersebut masih dibawah dari industri kerupuk ikan Sumber Rezeki di Gunung Anyar, Kota Surabaya dengan Net B/C sebesar 32 dengan waktu pengembalian modal kurang dari 2 bulan (Wahida et al., 2015). Kriteria-kriteria kelayakan usaha tersebut diatas menunjukkan bahwa produksi kerupuk ikan di UKM ABIZAR sangat layak untuk dijalankan dan mampu memberikan keuntungan.

Tabel 1. Asumsi umum yang digunakan dalam analisis kelayakan finansial.

\begin{tabular}{|c|c|c|c|}
\hline No & Variabel & Satuan & Nilai / Jumlah \\
\hline 1 & Periode Usaha & tahun & 5 \\
\hline 2 & Bulan kerja dalam 1 tahun & bulan & 12 \\
\hline \multirow[t]{7}{*}{3} & Output, Produksi dan Harga: & & \\
\hline & a. Produksi per bulan & $\mathrm{Kg}$ & 1,015 \\
\hline & b. Produksi per hari & $\mathrm{Kg}$ & 35 \\
\hline & c. Hari kerja dalam 1 bulan & hari & 29 \\
\hline & d. Harga penjualan & $\mathrm{Rp} / \mathrm{Kg}$ & 25,000 \\
\hline & e. Lama menunggu pendapatan & hari & 5 \\
\hline & f. Estimasi produk gagal & persen & $2.0 \%$ \\
\hline \multirow[t]{3}{*}{4} & Tenaga kerja : & & \\
\hline & a. Tetap & orang & 4 \\
\hline & b. Tidak tetap & orang & \\
\hline \multirow[t]{3}{*}{5} & Penggunaan input dan harga/bulan & & \\
\hline & a. Bahan baku utama & $\mathrm{kg}$ & 580 \\
\hline & b. Harga & $\mathrm{Rp} / \mathrm{kg}$ & 8,000 \\
\hline 6 & Suku Bunga per Tahun & $\%$ & $12 \%$ \\
\hline \multirow[t]{3}{*}{7} & Proporsi Modal : & & \\
\hline & a. Kredit & $\%$ & $0 \%$ \\
\hline & b. Modal Sendiri & $\%$ & $100 \%$ \\
\hline
\end{tabular}

Tabel 2. Biaya Investasi

\begin{tabular}{|c|c|c|c|c|c|c|}
\hline No & $\begin{array}{c}\text { Komponen } \\
\text { Biaya }\end{array}$ & Jumlah & $\begin{array}{c}\text { Harga } \\
\text { Satuan } \\
\text { Rp }\end{array}$ & $\begin{array}{c}\text { Jumlah } \\
\text { Biaya } \\
\text { Rp } \\
\end{array}$ & $\begin{array}{c}\text { Umur } \\
\text { Ekonomis } \\
\text { (tahun) } \\
\end{array}$ & $\begin{array}{c}\text { Nilai } \\
\text { Penyusutan } \\
\text { Rp } \\
\end{array}$ \\
\hline & BANGUNAN & & & & & \\
\hline 1 & $\begin{array}{l}\text { Sewa Bangunan } \\
\text { PERALATAN }\end{array}$ & 1 & $25,000,000$ & $25,000,000$ & 5 & $5,000,000$ \\
\hline 2 & Timbangan & 1 & 120,000 & 120,000 & 5 & 24,000 \\
\hline 3 & Kompor Gas & 2 & 400,000 & 800,000 & 5 & 160,000 \\
\hline 4 & Blender & 3 & 600,000 & $1,800,000$ & 5 & 360,000 \\
\hline 5 & Mixer & 1 & $5,000,000$ & $5,000,000$ & 5 & $1,000,000$ \\
\hline 6 & Mesin Pemotong & 1 & $8,000,000$ & $8,000,000$ & 5 & $1,600,000$ \\
\hline 7 & Lemari Bahan & 1 & $3,500,000$ & $3,500,000$ & 5 & 700,000 \\
\hline
\end{tabular}




\begin{tabular}{clccccc}
\hline No & $\begin{array}{c}\text { Komponen } \\
\text { Biaya }\end{array}$ & Jumlah & $\begin{array}{c}\text { Harga } \\
\text { Satuan } \\
\text { Rp }\end{array}$ & $\begin{array}{c}\text { Jumlah } \\
\text { Biaya } \\
\text { Rp }\end{array}$ & $\begin{array}{c}\text { Umur } \\
\text { Ekonomis } \\
\text { (tahun) }\end{array}$ & $\begin{array}{c}\text { Nilai } \\
\text { Penyusutan } \\
\text { Rp }\end{array}$ \\
\hline 8 & Meja & 1 & $1,000,000$ & $1,000,000$ & 5 & 200,000 \\
9 & Rak pendingin & 1 & $4,700,000$ & $4,700,000$ & 5 & 940,000 \\
10 & Baju Kerja & 45 & 45,000 & $2,025,000$ & 5 & 405,000 \\
11 & Panci Pengukus & 2 & $1,000,000$ & $2,000,000$ & 5 & 400,000 \\
\hline & Jumlah & & & $53,945,000$ & & $10,789,000$ \\
\hline
\end{tabular}

Tabel 3. Arus kas dan Kelayakan Usaha

\begin{tabular}{llcrll}
\hline & Uraian & Satuan & Nilai & Keterangan \\
\hline $\mathrm{A}$ & Biaya Investasi & $\mathrm{Rp}$ & $53,945,000$ & \\
$\mathrm{~B}$ & & Biaya Produksi/Cost (C) & & & \\
& 1 & Biaya Tetap /Fixed Cost (FC) & $\mathrm{Rp}$ & $4,935,000$ & \\
& 2 & Biaya Tidak tetap/Variable Cost (VC) & $\mathrm{Rp}$ & $10,785,000$ & \\
& 3 & Depresiasi & & $10,789,000$ & \\
& 4 & Total Biaya Produksi /Total Cost (TC) & $\mathrm{Rp}$ & $15,720,000$ & \\
& 5 & Biaya Produksi Per unit & $\mathrm{Kg}$ & 16,373 & \\
$\mathrm{C}$ & & Penerimaan / Total Revenue (TC) & $\mathrm{Rp}$ & $24,867,500$ & \\
$\mathrm{D}$ & & Keuntungan & & & \\
& 1 & Keuntungan Sebelum Pajak & $\mathrm{Rp}$ & $8,248,417$ & \\
& 2 & Laba Setelah Pajak & $\mathrm{Rp}$ & $7,011,154$ & \\
$\mathrm{E}$ & & Profit on Sales & $\%$ & $28.19 \%$ & \\
$\mathrm{~F}$ & Harga Jual per Unit & $\mathrm{Rp}$ & 25,000 & \\
$\mathrm{G}$ & & Break Event Point (BEP) & & & \\
& 1 & BEP atas dasar Sales & $\mathrm{Rp}$ & $10,302,081.8$ & \\
& 2 & BEP atas dasar Unit & $\mathrm{Kg}$ & 845.8 & \\
$\mathrm{H}$ & Revenue Cost Ratio (R/C Ratio) & $\%$ & 1.50 & $\mathrm{R} / \mathrm{C}>1$ \\
$\mathrm{I}$ & Rentabilitas (R) & $\%$ & $40 \%$ & $\mathrm{R}>14 \%$ \\
$\mathrm{~K}$ & Benefit-Cost Ratio (Net B/C) & & 5.03 & Net B/C>0 \\
L & NPV (14\%) & $\mathrm{Rp}$ & $18,115,284.62$ & NPV>0 \\
M & Payback Period (PP) & Tahun & 0.47 & \\
\hline
\end{tabular}

\section{CONCLUSION}

UKM secara umum layak dijalankan dari berbagai aspek diatas. Dari aspek finansial yang merupakan indikator utama kelayakan usaha, adanya rasio keuntungan yang sangat besar net $B / C$ ratio yang mencapai 5,05 ,Rentabilitas $40 \%$, dan $R / C$ Ratio 1,5 serta paypback period kurang dari setengah tahun, maka usaha ini sangat layak usaha dan dapat diteruskan. Dari kelayakan usaha tersebut juga dapat disimpulkan jika pendampingan usaha dengan memberikan bantuan peralatan produksi tidak membebani keuangan pengusaha dan malah sebaliknya meningkatkan efisiensi dan kentungan usaha. Namun demikian perlu adanya perbaikan terutama dari aspek legalitas usaha karena UKM mitra belum memiliki legalitas sama sekali.

\section{ACKNOWLEDGEMENT}

Kegiatan pengabdian masyarakat ini merupakan bagian dari rangkaian Program Pengembangan Desa Mitra (PPDM) Universitas Brawijaya. Penulis mengucapkan terima kasih kepada LPPM-UB dan DRPM Kemeristek/BRIN. Kegiatan ini dibiayai oleh Direktorat Riset dan Pengabdian Masyarakat Deputi Bidang Penguatan Riset dan Pengembangan, Kementerian 
Riset dan Teknologi/Badan Riset dan Inovasi Nasional dengan Perjanjian Pendanaan Pelaksanaan Program Pengabdian Masyarakat Nomor: 043/SP2H/PPM/DRPM/2021, Tanggal 23 Maret 2021. Selain itu penghargaan juga ditujukan kepada Kepala Desa Pangkahkulon beserta seluruh perangkat desa dan masyarakat yang telah membantu kelancaran kegiatan pengabdian masyarakat ini.

\section{REFERENCES}

Agustina, T., \& Saputro, D. D. (2018). Pengolahan Kerupuk Kulit Ikan Di Kelurahan Bulu Lor Kota Semarang. Rekayasa: Jurnal Penerapan Teknologi Dan Pembelajaran, 16(1), 113-118. https://journal.unnes.ac.id/nju/index.php/rekayasa/article/view/15097.

Aliviyanti, D., Semedi, B., Yona, D., Asadi, M. A., Kasitowati, R. D., Dewi, C. S. U., Lutfi, O. M., \& Isdianto, A. (2021). Upaya Penguatan Manajemen Pemasaran Hasil Perikanan Berbasis Media Online di TPI Sendangbiru, Kabupaten Malang, Indonesia. Abdi Geomedisains, 59-67.

Asyari, A. (2016). Pemberdayaan ekonomi ibu-ibu rumah tangga di Desa Petuluan Indah Lingsar melalui pengembangan manajemen pemasaran home industri (kerupuk ikan). Transformasi: Jurnal Pengabdian Masyarakat, 12(2), 198-216.

Erlina, S., Ifada, I., \& Supianor, S. (2016). Prospek Usaha Pembuatan Kerupuk Ikan Gabus. Ziraa'ah Majalah Ilmiah Pertanian, 41(2), 237-242. https://doi.org/10.31602/zmip.v41i2.426.

Fakhrida, A., Mahreda, E. S., \& Mustika, R. (2016). Analisis Usaha Pengolahan Kerupuk Ikan Tenggiri (Scomberomorus commersoni) Skala Rumah Tangga di Kecamatan Pulau Laut Utara Kabupaten Kotabaru Provinsi Kalimantan Selatan. EnviroScienteae, 12(2), 63. https://doi.org/10.20527/es.v12i2.1682.

Firdaus, M., \& Intyas, C. A. (2020). Efisiensi Kapasitas dan Biaya Produksi Kerupuk Ikan melalui Penggunaan Mesin Pengadonan pada UKM Maharani. PengabdianMu: Jurnal Ilmiah Pengabdian Kepada Masyarakat, 5(2), 185-191. /https://doi.org/10.33084/pengabdianmu.v5i2.1079.

Fuad, M. A. Z., Iranawati, F., Kartikaningsih, H., \& Rosalina, K. (2020). Peningkatan Produksi dan Kualitas Produk Unggulan Kerupuk Ikan Desa Pangkahkulon Kecamatan Ujung Pangkah-Gresik Jawa Timur. PengabdianMu: Jurnal Ilmiah Pengabdian Kepada Masyarakat, 5(2), 203-209. https://doi.org/10.33084/pengabdianmu.v5i2.1045.

Fuad, M A Z, Iranawati, F., \& Nurdiani, R. (2019). Peningkatan Produksi dan Pengembangan Industri Rumah Tangga (IRT) Ikan Asap di Desa Banyuurip-Ujungpangkah-Gresik. $J$ Dinamika: Jurnal Pengabdian Masyarakat, 4(1). https://doi.org/10.25047/jdinamika.v4i1.1059.

Fuad, M A Z, Sartimbul, A., Iranawati, F., Sambah, A. B., Yona, D., Harlyan, L. I., Hidayati, N., Rahman, M. A., \& Sari, S. H. J. (2019). Metode Penelitian Kelautan dan Perikanan: Prinsip Dasar Penelitian, Pengambilan Sampel, Analisis, dan Interpretasi Data. Universitas Brawijaya Press.

Fuad, Mochamad Arif Zainul, Iranawati, F., \& Kartikaningsih, H. (2020). Laporan Akhir Program Pengembangan Desa Mitra (PPDM) : Pengembangan Desa Sentra Kerupuk Ikan Pangkahkulon Di Kecamatan Ujungpangkah - Gresik.

Harahap, Y. R. (2014). Kemampuan menyusun laporan keuangan yang dimiliki pelaku ukm dan pengaruhnya terhadap kinerja UKM. Jurnal Riset Akuntansi Dan Bisnis, 14(1). http://dx.doi.org/10.30596\%2Fjrab.v14i1.156.

Herlambang, A., Asmawati, E., \& Haryono, Y. (2018). Implementasi Cara Produksi Pangan yang Baik untuk Industri Rumah Tangga Kerupuk di Sidoarjo (Implementation of Good 
Food Production Method for Kerupuk Household Industry in Sidoarjo ). Agro Kreatif, 4(1), 31-37. /doi.org/10.29244/agrokreatif.4.1.31-37.

Hidayati, D. R. (2016). Strategi Komunikasi Pemasaran Usaha Skala Mikro (Micro Enterprise) Kub Bajrah Gunah Klampis Bangkalan Pada Produk Terasi, Petis Dan Kerupuk Ikan. Agriekonomika, $5(1)$,

104-112. https://doi.org/10.21107/agriekonomika.v5i1.1467.g1258.

Hudayana, B., made Kutanegara, P., Setiadi, S., Indiyanto, A., Fauzanafi, Z., Nugraheni, M. D. F., Sushartami, W., \& Yusuf, M. (2019). Participatory Rural Appraisal (PRA) untuk Pengembangan Desa Wisata di Pedukuhan Pucung, Desa Wukirsari, Bantul. Bakti Budaya, 2(2), 3-16. https://journal.ugm.ac.id/bakti/article/view/50890.

Ihwah, A., \& Setiyawan, D. T. (2018). IbM UKM Kerupuk Ikan Di Desa Pangkah Wetan Kecamatan UjungPangkah Kabupaten Gresik Jawa Timur. Jurnal Akses Pengabdian Indonesia, 3(1), 1-6. https://jurnal.unitri.ac.id/index.php/japi/article/view/638.

Iranawati, F., Fuad, M. A. Z., \& Kartikaningsih, H. (2017). Laporan Akhir Program Doktor Mengabdi "Pemetaan Potensi Desa Pangkahkulon, Kec. Ujung Pangkah-Kab. Gresik berbasis Sistem Informasi Geografis."

Kurniasih, R. A., Fahmi, A. S., \& Fitria, S. (2019). Peningkatan Produktivitas dan Mutu Produk Poklahsar Pengolah Kerupuk Ikan di Kota Tegal dengan Teknologi Tepat Guna. Seminar Nasional Kolaborasi Pengabdian Kepada Masyarakat, 436-441. https://www.google.com/url? .

Kusumaningrum, I., \& Asikin, A. N. (2016). Karakteristik Kerupuk Ikan Fortifikasi Kalsium Dari Tulang Ikan Belida. Jphpi, 19(3), 233-240. https://doi.org/10.17844/jphpi.2016.19.3.233.

Latif, R., Dirpan, A., \& Indriani, S. (2017). The Status of Implementation of Good Manufacturing Practices (GMP) Shredded Fish Production in UMKM Az-Zahrah, Makassar. IOP Conference Series: Earth and Environmental Science, 101(1), 0-6. https://doi.org/10.1088/1755-1315/101/1/012040.

Latifiana, D. (2017). Studi Literasi Keuangan Pengelola Usaha Kecil Menengah (UKM). Prosiding Seminar Pendidikan Ekonomi Dan Bisnis, 3(1). https://jurnal.fkip.uns.ac.id/index.php/snpe/article/view/10635/7704.

Maharani, I. Y., Nosita, F., \& Asruni, A. (2018). Analisis Kelayakan Usaha Pengolahan Ikan Pada Industri Kecil Casheila Banjarbaru. Jurnal Ilmiah Ekonomi Bisnis, 4(3), 301-318. https://doi.org/10.35972/jieb.v4i3.235.

Margowati, S., Masithoh, R. F., \& Dewi, V. S. (2018). Pengembangan Agribisnis Ikan Tawar Melalui Penguatan Poktan/Pokdakan Desa Bojong, Kecamatan Mungkid, Kabupaten Magelang. Community Empowerment, 3(2), 71-75. https://doi.org/10.31603/ce.v3i2.2470.

Mokhtar, A. (2019). Penerapan Teknologi Mesin Pencetak Kerupuk Singkong Pada Kelompok Industri Kerupuk Dusun Ngandat Mojorejo Kota Batu. Prosiding SENTRA (Seminar Teknologi Dan Rekayasa), 5, 7-12. https://doi.org/10.22219/sentra.v0i5.3009.

Musthofa, Z., \& Ainiyah, R. (2018). Analisis Usaha Terasi Udang di Desa Tambak Lekok Kabupaten Pasuruan. Teknologi Pangan: Media Informasi Dan Komunikasi Ilmiah Teknologi Pertanian, 9(2), 123-131. https://doi.org/10.35891/tp.v9i2.1191.

Nadya, Y., \& Yusnawati. (2018). Analisa Kelayakan Usaha Kerupuk Ikan Kota Langsa. Jurnal Teknik Industri, 21(01), 1-10. https://univ45sby.ac.id/jurnal/index.php/industri/article/view/203/114114125.

Ningsih, R. S., Mudzakir, A. K., \& Rosyid, A. (2013). Analisis Kelayakan Finansial Usaha Perikanan Payang Jabur (Boat Seine) di Pelabuhan Perikanan Pantai Asemdoyong Kabupaten Pemalang. Journal of Fisheries Resources Utilization Management and Technology, $2(3)$, $223-232$. 
https://ejournal3.undip.ac.id/index.php/jfrumt/article/download/3852/3755.

Prahutama, A. (2019). Peningkatan Olahan Ikan Bandeng Menuju Produk Ekspor Di Kabupaten Pati, Jawa Tengah. http://ejurnal.unisri.ac.id/index.php/sndms/article/view/3290/2772.

Prasetyowati, D., Rasiman, R., \& Minarti, I. B. (2019). Pemberdayaan Masyarakat Desa Bendar Kecamatan Juwana Kabupaten Pati Menuju Desa Sentra Kerupuk Ikan. Jurnal $\begin{array}{llll}\text { Pengabdian Kepada } & \text { Masyarakat, } & \text { 25(2), }\end{array}$ https://doi.org/10.24114/jpkm.v25i2.14593.

Primyastanto, M. (2011). Feasibility Study Usaha Perikanan. Universitas BrawijayaPress. Malang. Xvi, 218.

Purnengsih, I., Pratama, D., Amzy, N., \& Pramudita, P. (2021). Model Desain Kemasan Untuk Pelaku Usaha Kerupuk Mie Karadenan Bogor di Era New Normal. Adi Widya: Jurnal Pengabdian Masyarakat, 5(1), 64-73.

Putri, R. A. I., Rohayati, Y., \& Aisha, A. N. (2015). Evaluasi Pemenuhan Kriteria Cppb-Irt Dan Sertifikasi Halal Pada Ukm Pelangi Rasa. Jurnal Rekayasa Sistem \& Industri (JRSI), 2(03), 17. https://doi.org/10.25124/jrsi.v2i03.60.

Rahmayuni, S. (2017). Peranan Laporan Keuangan dalam Menunjang Peningkatan Pendapatan Pada UKM. JSHP: Jurnal Sosial Humaniora Dan Pendidikan, 1(1), 93-99. https://doi.org/10.32487/jshp.v1i1.239.

Ramli, Setiawan, B., Santoso, I., \& Mustaniroh, S. A. (2019). Analisis Kelayakan Usaha dan Nilai Tambah Kerupuk Cumi. Jurnal Keuangan Dan Bisnis, 17(1), 32-50. https://doi.org/DOI : 10.32524/jkb.v17i1.494.

Riyadi, N., \& Mujanah, S. (2021). Strategi Pemasaran dan Pendampingan Manajemen Usaha Kelompok Usaha Kecil Kerupuk di Kenjeran Kota Surabaya. Jurnal Ilmiah Abdi Mas $T P B$ Unram, $3(1)$. http://abdimastpb.unram.ac.id/index.php/AMTPB/article/view/56/48.

Sarwono, E., Sutarmin, A., Ruhama', U., Suwarni, L., \& Selviana, S. (2018). PKM Inovasi Teknologi Produksi Olahan Ikan Pada Poklahsar Desa Kuala Secapah. JPP IPTEK (Jurnal Pengabdian Dan Penerapan IPTEK), 2(2), 27-34. https://doi.org/10.31284/j.jpp-iptek.2018.v2i2.307.

Setyaningrum, A., \& Hartanto, B. W. (2020). Peningkatan Kapasitas Istri Nelayan Dalam Pengolahan Hasil Perikanan Di Dusun Kuwaru Desa Poncosari, Kecamatan Srandakan, Kabupaten Bantul. Jurnal Panrita Abdi-Jurnal Pengabdian Pada Masyarakat, 4(2), 184-194. https://journal.unhas.ac.id/index.php/panritaabdi/article/view/7740/4890.

Sofia, L. A. (2011). Analisis Prospek Industri Pengolahan Kerupuk Ikan Patin "Intan Sari” Di Martapura, Kabupaten Banjar. Fish Scientiae, 1(2), 146-160.

Sriningsih, E., Santoso, E. B., \& Supriyono, Y. (2017). Peningkatan kuantitas dan kualitas pemotongan kerupuk di kelompok ukm kerupuk Sidoarjo. Prosiding Seminar Nasional Hasil Pengabdian Kepada Masyarakat (SENIAS) 2017 Universitas Islam Madura, 120-123. http://senias.uim.ac.id/index.php/senias_2017/article/view/30.

Sudarismiati, A., \& Syaifullah. (2015). Analisis Kelayakan Usaha Krupuk Ikan UD. Masmun dalam Rangka Meningkatkan Pengembangan Usaha di Desa Nogosari Kecamatan Sukosari Kabupaten Bondowoso. Growth, 15(2), 16-29. https://unars.ac.id/ojs/index.php/Growth/article/view/39.

Sukrie, A., \& Nadia, L. (2010). Meningkatkan Daya Terima, Preferensi dan Keterpilihan Produk Krupuk Ikan dan Kerupuk Udang Sesuai Segmentasi Pasar. Prosiding Seminar Nasional Pangan Fungsional, 190-198. http://perpustakaan.pertanian.go.id/repository_litbang/uploaded_files/BPTP_Jabar/04 _25.pdf. 
Suwarni, L., Sarwono, E., Suryadi, E., \& Selviana, S. (2020). Sosialisasi Strategi dan Web Pemasaran Online (PPDM di Desa Rasau Jaya Satu). International Journal of Community Service Learning, 4(4), 274-281. https://doi.org/10.23887/ijcsl.v4i4.29246.

Wahdah, W., Mahreda, E. S., \& Lilimantik, E. (2016). Kajian Kelayakan Usaha Pengolahan Kerupuk Ikan Pipih Di Kabupaten Barito Kuala Kalimantan Selatan. EnviroScienteae, 12(2), 113. https://doi.org/10.20527/es.v12i2.1689.

Wahida, A. M., Primyastanto, M., \& Utami, T. N. (2015). Pengembangan Usaha Kerupuk Ikan Payus (Elops hawaiensis) Pada UD. Sumber Rezeki Kelurahan Gunung Anyar Tambak, Kecamatan Gunung Anyar, Kota Surabaya, Jawa Timur. ECSOFiM, 3(1), 39-47. https://www.ecsofim.ub.ac.id/index.php/ecsofim/article/view/29.

Wahyuni, T., Nurliza, N., \& Kurniati, D. (2017). Preferensi Konsumen Terhadap Pembelian Kerupuk Ikan Di Kota Sintang. Jurnal Social Economic of Agriculture, 6(1), 101. https://doi.org/10.26418/j.sea.v6i1.21592.

Winarti, L., Herlina, S., \& Permadi, R. (2018). Analisis Kelayakan dan Model Pengembangan USAha Kerupuk Ikan dengan Pendekatan Entreprenuerial Marketing. Jurnal Agribest, 2(2), 92. https://doi.org/10.32528/agribest.v2i2.1622.

Yurian, S. R., Manik, T., \& Adel, J. F. (2020). Analisis Revenue Cost Ratio, Payback Period dan Break Even Point Untuk Menilai Kelayakan Usaha Pada Usaha Kerupuk di wilayah Kelurahan Sei. Lekop Kecamatan Bintan Timur Kabupaten Bintan. Student Online Journal, $1(2)$, 342-349. https://soj.umrah.ac.id/index.php/SOJFE/article/view/607/529. 